\title{
The Pragmatics of Chinese Proverb Quoting in the English and the Russian-Language Mass Media of PRC
}

\author{
Olga V. Nikolaeva ${ }^{1} \&$ Ekaterina A. Yakovleva ${ }^{1}$ \\ ${ }^{1}$ Oriental Institute - School of International and Regional Studies, Far Eastern Federal University, Russia \\ Correspondence: Olga V. Nikolaeva, Oriental Institute - School of International and Regional Studies, Far \\ Eastern Federal University, Vladivostok, Office D 720, bld. 20, Campus FEFU, Russky Island, Russia. E-mail: \\ nikolaeva.ov@dvfu.ru
}

$\begin{array}{lr}\text { Received: January 27, } 2015 & \text { Accepted: February 25, } 2015 \quad \text { Online Published: May 15, } 2015 \\ \text { doi:10.5539/ass.v11n15p211 } & \text { URL: http://dx.doi.org/10.5539/ass.v11n15p211 }\end{array}$

\begin{abstract}
Mass media of PRC in languages others than Chinese native (in the present research English and Russian) are a form of cross-cultural communication between China and the rest of the world. In other-language mass media China not only presents its views and attitude to the events described, but also reveals China "the whole self" by employing the fragments of its traditional verbal culture, proverbs in particular being the ways of self-expression. However, the research provided evidence that the foreign-language press of China carefully considers the appropriateness of proverb quotations, and thoroughly estimates the degree of transmitted by them informal and indirect culture-based information, which the target audience is capable or incapable to grasp, share, and abide by. Proverbs generally being among the most indirect strategies of reasoning and persuasion in some contextual use may convey straightforward and strict judgments. The paper studies significant theoretical issues and application aspects of proverb quoting in the foreign-language press of PRC which depends on crucial questions of cross-cultural pragmatics: first, the addressor's natural urge for culture-based self-expression alongside with striving for intelligibility to the foreign target audience, and second, the addressor's choice of higher / lower context in communication with different cultures-addressees. This accounts for the discrepancy between presentation of information in the English-language press of PRC and the Russian-language periodical of China. Both questions suggest a wide range of options in proverb quoting (preserving/omitting a proverb, original proverb with glossing / loan translation, meaning / connotation modulation of a proverb, etc).
\end{abstract}

Keywords: Paremiology, cross-cultural Pragmatics, Chinese proverb, mass media, Cino-Japanese relations

\section{Introduction}

Pragmatics and discourse analysis of proverbs as Chilukuri (2014) puts it "are relatively recent phenomena in the long history of Paremiology" (p. 2). Further differentiation and specialization of the subject matter within the research field of Paremiology (cognitive, pragmatic, functional, anthropological, psychological, cultural, etc.) is now perceived as a natural progress of study, and a distinguishing feature of the contemporary stage of proverbial knowledge. This ongoing process has already given rise to various recent interpretations of a proverb. The particular frameworks of split approaches in modern Paremiology specified some significant proverb characteristics, and made them conspicuously stand out against the background of traditional proverb interpretation.

Integration and interaction of Paremiology, Pragmatics, and Discourse analysis in the present research seems promising for theoretical and empirical reasons. The study of a proverb use within the field of Pragmatics sheds light on contemporary cultures, societies, and social groups by tracing their values (either traditional or changing), their collective cognition and worldviews.

Mass media discourse analysis exposes the ideological aspects of a proverb use by viewing a proverb as a tool of setting up attitudes and giving prescriptions to masses in an unobtrusive way of traditional folk wisdom.

The proverbs of China due to their frequency and recurrence in contemporary mass media not only Chinese, but also global, deserve special study.

Chinese mass media in English and in Russian, i.e. mass media of PRC in languages others than Chinese native, present an interesting case of a Chinese proverb use. Since such media are primarily aimed at foreign target 
audience, they may be considered a cross-cultural communication phenomenon. Chinese proverbs when used in foreign-language periodicals present China "the self" to the rest of the world through authentic verbal culture and reveal China's attitude towards 'others' via experience of elder generations.

William Scarborough, a Wesleyan missionary in Hankow back in 1875 described a Chinese proverb as "something almost, if not utterly, indefinable" (Scarborough, 1875, p. V), and emphasized uniqueness of a Chinese proverb in comparison with other countries' proverbs: "Of course it bears, in several features, a strong likeness to other branches of the family in various countries; but, of "that sententious brevity," which is said to "constitute the principal beauty of a proverb" - of that brevity without obscurity, which is said to be the very soul of a proverb, it is often totally lacking. Other features it has which are peculiarly its own, and which impart to it a terseness, beauty, and symmetry, inimitable, at least in the English language." (p. V).

A lot of significant theoretical issues and application questions arise concerning translation of Chinese proverbs, their possible subsequent global dissemination as loan translations, their modulation in the recipient cultures and languages. Since Chinese traditional proverbs when used in global media frequently pass through multiple transformations of either form, or meaning, it often takes much effort to identify a proverb alleged as Chinese. Close to this, the origin of a proverb, sometimes erroneously ascribed to it in mass media, is another hot issue in modern Paremiology.

Though Chinese proverbs are currently quoted around the globe more frequently than ever, and hence might be of great research significance, they habitually become an object of Paremiography, rather than Paremiology. Modern Paremiology needs more empirical data on Chinese proverb use worldwide, more studies on circulation of loan translation of Chinese proverbs. Mieder (1997a) emphasizes that "modern theoretical and empirical paremiology will doubtlessly lead to new insights about human behavior and communication, and by comparing these research results on an international basis, paremiologists might add their bit to a humane and enlightened world order based on experienced wisdom." (p. 416).

With this in mind the research of Chinese proverb quoting was done in the paradigm of mass media Pragmatics, considering a proverb use in terms of the addressor-addressee interaction. Since we study a Chinese proverb use in the English- and the Russian-language mass media of PRC our prime target was cross-cultural interaction between China - the addressor and other cultures - addressees.

\section{Area descriptions}

\subsection{Paremiology}

Any scholarly essay should normally start with an operational definition of a basic category, which in the present case is a proverb. Interestingly enough Rev. William Scarborough introducing his $19^{\text {th }}$ century Collection of Chinese Proverbs (1875) wrote that "definitions of proverbs in general have not been attended with very great success; certainly they have not been very unanimous." (p. IV). Many scholars quoted Lord John Russell's definition - "The wisdom of many, and the wit of one", or Tennyson's words: "Jewels five-words long, // That, on the stretch'd fore-finger of all Time, // Sparkle for ever." (p. V).

The search for a single unanimous definition of a proverb in modern Paremiology is still a tough job. Today defining a proverb is perhaps even a more challenging task for paremiologists than decades before. Since Taylor published his outstanding book on proverb exploration in 1931 the field of Paremiology has grown fast and vast encompassing the whole range of research aspects: structural linguistic, functional, cognitive, pragmatic, anthropological, psychological, cultural, sociological, etc., all instituting their specific paradigms for a proverb interpretation. The study of proverbs has found itself linked to lots of other humanitarian fields becoming as Mieder (1997a) put it "an absolutely open-ended phenomenon with many new challenges lying ahead." (p. 416). Contemporary surveys traditionally prefacing scholarly research on proverbs being unable to review all paremiology studies can only by Mieder's bright metaphor "scratch the proverbial surface" (1997a, p. 399). In the situation when it is not easy to reconcile various approaches and different views on a proverb interpretation, scholars either keep seeking "a centrally co-ordinated orientation" (Chilukuri, 2014, p. 4), or agree on certain defining characteristics of a proverb rather than its single definition.

Acknowledging that modern Paremiology naturally splits into subfields, cognitive, pragmatic, anthropological, psychological, cultural, etc., all giving rise to multiple new interpretations of a proverb, one should be conscious of the fact that the study of proverbs is a long story dating back to Aristotle and Plato, and recent proverb definitions however different grew up from the common scholarly ground and inherited the set of traditional features. These attributes now differently disseminated through various recent proverb interpretations reveal the very essence of a proverb regardless of the particular research aspect. Yet, perhaps, due to the basic and 
axiomatic nature, these qualities are often reduced in present-day definitions or obscured by newly-defined proverb characteristics fostered in the specific fields where proverbs have only recently become an object of research.

Giving much consideration to various definitions of a proverb Mieder (2004) states: "It is my contention that not even the most complex definition will be able to identify all proverbs." (p. 4). Chilukuri (2014) came to the conclusion that "none of them has successfully captured the defining characteristics of proverbs that will account for the universal characteristic that constitutes a proverb and the distinguishing characteristic that differentiates a proverb from an item of another genre." (p. 19).

In contrast with the apparent difficulty to give proper emphasis to all essential properties of a proverb in a single definition a proverb characterization (not a definition) within any specific branch of paremiological study seems though a middle-of-the-road result but quite an attainable goal (Yakovleva \& Nikolaeva, 2014, p. 148). It should start with the basic features of a proverb and comprise as well those characteristics which a proverb obtains from the specific research field (Pragmatics, Anthropology, Psychology, Discourse analysis, Intertextuality approach, etc.).

Since Aristotle characterized proverbs as "fragments of an elder wisdom", Paremiology with respect to the ancient scholarly tradition has viewed proverbs as generationally-tested, experienced folk wisdom, which provides the insight into the value system of a speech community, and the insight into its worldview (Mieder 1997a, p. 410, 416). Consistently proverbs have been appreciated, preserved and cited through years or over centuries due to their fixed form, brevity, pithiness, aptness, didactic content (Norrick, 1985, p. 31). These qualities of proverbs built up the foundation, upon which many recent theories have risen.

\subsection{Pragmatics of Proverb Quoting}

Contemporary paremiologists have substantially widened the scope of proverbial knowledge by inquiring into such questions as "What rules govern the use of proverbs? Who is using them and to whom? On what occasions? In what places?" (Mieder, 1997a, p. 411). Mieder states that proverbs are after all "not universal truths but rather limited pieces of folk wisdom which are valid only in certain situations." (p. 410). This generated the latest trends in Paremiology studying contextual use of proverbs, among them - the pragmatics of proverb quoting in mass media discourse.

Pragmatics is a subfield of linguistics which deals primarily with speech variation arising from distinguishing between informative meaning of the sentence and communicative intents of the author of the utterance as in Shaozhong Liu (2000, p. 382). Respectively the pragmatics of proverb quoting focuses on the contextual and indexical meaning and communicative functions of proverbs in use.

Pragmatics in cross-cultural communication calls for studying cultural differences in speaker-hearer speech interaction. This approach widens the horizon of a proverb study by exploring the cultural environment in which proverbs flourish, i.e. cultural background, culturally-biased communicative situation and type of discourse. All affect the meaning of a proverb and enlarge the scope of proverb functions.

Much attention of contemporary paremiologists is drawn to the use of proverbs in public speeches of statesmen and government authorities on different occasions (Dabaghi, Pishbin \& Niknasab, 2010, p. 810). Proverbs used by well-known politicians were investigated in the books and essays of the renowned paremiologist Wolfgang Mieder "The Politics of Proverbs: From Traditional Wisdom to Proverbial Stereotypes" (1997b), "Proverbs are the Best Policy: Folk Wisdom and American Politics" (2005), "The Golden Rule as a Political Imperative for the World President Barack Obama's Proverbial Messages Abroad" (2010).

According to Mieder (1997a, 1997b), political discourse profiles manipulative use of proverbs by politicians "to push through a definite political agenda." A proverb used in political discourse is on the one hand a rhetorical device (Mieder, 2005) and on the other a social strategy "for the masses to conduct in accordance to the requirements of the society" (Wen Zhao, 2012, p. 2076).

The "social strategy" function though seemingly inherent in each proverb is probably more conspicuous in the so called "social proverbs", i.e. those which reveal "the social dimension of culture" (Wen Zhao, 2012: 2076). Studying social proverbs Wen Zhao (p. 2076) states that being oriented towards an addressee, either an individual, or a social group, they "convey ideologies, views on society and nature, to the broader masses" (p. 2076). "By entering individual consciousnesses, social proverbs affect or even shape consciousnesses with world views, belief and value systems." (p. 2079). Such proverbs eventually influence public perception and behavior (p. 2079). 
Mass media frequently performing the role of exerting influence on public employs proverbs in political or social news items for the similar purposes.

According to the formal structure of mass media information a proverb may be found in the headline, introduction (news topic), basic text, or conclusion. This prominently shapes another not the least important structural basis for distinguishing proverb functions, though subordinate to its being an effective tool of presetting the required mode to news perception.

Norrick (1985) states that a proverb is cited especially in the headlines, and this position signals of the "template function of proverbs" (p. 24). Dabaghi, Pishbin and Niknasab (2010) point out that "in press, hot news is circulated through a proverb in the heading or text of it which reflect news topic." (p. 810). The template function of proverbs hits the pragmatic goals of news coverage "to disambiguate complex situations and events" (Mieder, 1997a: 410) in the "right" guided way. A proverb shapes public opinion by creating a preset metaphorical scenario which frames a news item in people's minds in accordance with the author's intentions.

A proverb may also be placed at the end of a news item, in its conclusion. It is a long standing truth, as in Taylor (1981), that a proverb "sums up the situation" (p. 5). Chilukuri (2014) states that a saying "summarizes a situation and in its own inimitable way passes some sort of judgment on it or characterizes its essence." (p. 8). In the latter case a proverb performs the summarizing function. Now it is not the template but the bottom line of the news item.

The cognitive foundation of the above mentioned framing functions calls for the deeper level of categories. The basis for the template role of a proverb is the intended analogy between the proverbial scenario and the event described scenario. The summarizing function of a proverb is based on the presumed logical inference, or the cause and effect assumption which a proverb conceives.

\section{Methods}

\subsection{Material Studied}

The Pragmatics of Chinese proverb quoting was studied on the material of the English- and the Russian-language newspapers issued in China (2011-2015): The China Daily (in English), The Global Times (in English), The People's Daily (both in English and in Russian). Using random sampling the news items on Cino-Japanese bilateral relations containing Chinese proverbs were selected. The number of Chinese proverb quotations analyzed for this research was more than two hundred.

It should be noted that no distinction was made as to the news items authors' ethnicity, with admission that there may be native Chinese, native English, or native Russian speakers. The point is that they all represent mass media of PRC, i.e. China-edited mass media, hence providing China insights and China views on domestic and international events. President Hu Jintao said about The People's Daily Online: "People.cn has played a unique role in advocating the Party's belief, guiding public opinion and warmly serving netizens since inception." (The People's Daily Online). The editorial description of the English-language Global Times states: "[the paper] is one of the most dynamic players among Chinese media, and has rapidly become the major English newspaper in the nation. $<\ldots .>$ The Global Times' readers, both foreign and Chinese, include ambassadors, business leaders, politicians, and intellectuals. China's top universities use the newspaper as a teaching tool for the nation's future elite. . < ...> The Global Times' unique partnership with the Global Poll Center keeps its finger on the pulse of the Chinese public, while an expanding online presence makes its unique insights even more accessible to a global audience." (The Global Times).

The China Daily Group "from print to digital media, from China to the Americas, Europe, Africa and the rest of Asia" provides "information, analysis, comment and entertainment for global readers with a special focus on China." (The China Daily Group).

\subsection{Techniques and Procedure}

The initial step of the present research was the topical sampling of the news items on Cino-Japanese relations from the English- and the Russian-language media of PRC. Out of that pool of news items those containing Chinese proverbs were selected.

Once empirical data was accumulated, we proceeded with the precise identification of each news subject. That was important for tracing those aspects of China-Japan bilateral relations which in news coverage conspicuously attracted Chinese proverbial interpretation. We also tried to investigate the causes for abundant use of Chinese proverbs in the Chinese media discourse about Japan. 
We applied analytical content-processing approach to the news fragments to state the functions and pragmatic strategies of Chinese proverbs use in reference to Japan. Since mass media communication with the one-to-many mode presents communicative intentions aiming at making abide by author's views and attitude, it was important to analyze proverbs in the aspect of affecting the audience.

We found it appropriate to study pragmatically-biased cross-cultural differences between proverbial interpretation of Cino-Japanese relations in the Russian-language and the English-language newspapers of PRC.

\section{Results and Discussion}

The research proceeds on the assumption that mass media of PRC in languages others than Chinese native (in the present paper the English- and the Russian-language press) are considered a cross-cultural communication phenomenon. This seems true because such media are primarily aimed at multinational foreign audience, to whom China in many ways and through multiple strategies (including traditional proverbial quotations) communicates its views, intentions, and attitude to the events described.

\subsection{Cino-Japanese Bilateral Relations through Proverb Quoting}

The study provided evidence that in Chinese cross-cultural media proverbial interpretation regularly targets the news on international relations of PRC. In accordance with the empirical data considerable repertoire of proverb quotations was found in the media coverage of Cino-Japanese bilateral relations:

'one hand alone can't clap'一个巴掌拍不响 (meaning: the responsibility lies with both parties);

'lose an axe, and blame the neighbor' 失斧疑鄰 (meaning: ignore the facts and make wrong assumptions about people or situations);

'a good neighbor is better than a brother far away' 遠親不如近鄰;

‘blood will have blood’ 血債血還;

'vengeance has a way of rebounding upon oneself' 冤冤相报何时了;

'a friend in need is more precious' 患難見交情;

'a thief who cries 'thief' 贼喊捉贼 (meaning : accuse sb. of the theft and try to sneak away oneself), etc.

Interestingly some of Chinese characters adapted in written Japanese though differ in meaning may convey the same sense and connotation. Accordingly some Chinese proverbs may be recognizable by the Japanese, such as the proverb 吴越同舟, 'being in the same boat' (meaning: even mortal enemies should help each other when facing common dangers or threats) (Cai, 2014, October 21). In this particular case the proverb may be the best strategy to describe the desired China-Japan bilateral relations. It graphically, meaningfully and symbolically emphasizes that China and Japan have much in common and may cooperate.

Investigating the causes for conspicuous employment of Chinese proverbs in reference to China-Japan relations we were basing on Edward Hall's (1989) dichotomy scaling world cultures from high to low context communication (p. 105). Both China and Japan fit the profile of high-context cultures. "A high context (HC) communication or message is one in which most of the information is already in the person, while very little is in the coded, explicit, transmitted part of the message." (E. Hall \& M. Hall, 1990, p. 8). Hence in communication few words may convey complex information, many things are only hinted at, and therefore the choice of words, verbal expression is of great importance.

Proverbs in China-Japan cross-cultural communication conceive much more unspoken than spoken. What is unspoken is to be drawn from the context and prior experience of China-Japan bilateral relations.

In this respect Chinese proverbs are excellent means of high context communication. They present synthesis of the event and the "context", i.e. the information that surrounds the event known to the in-group (including neighboring Japan). From the combination of the event and the "context" the actual meaning emerges. The example from The Global Times (Chinese spokeswoman blames Japan for tension, 2013, March 04) with the Chinese proverb 'you can't clap with one hand only'一个巴掌拍不响 [the responsibility lies with both parties] will suffice to illustrate the point: " $F u$ Ying, spokeswoman for the first session of the $12^{\text {th }}$ National People's Congress (NPC), the country's top legislature, said China is willing to resolve disputes through negotiations. However, "one hand alone can't clap," Fu said, quoting a Chinese proverb to indicate that Japan has failed to engage in negotiations."

The proverb 'one hand alone can't clap' cited on the topic of Cino-Japanese relations allegorically communicates the event, hints at the context, and the attitude, in other words, sufficiently provides the details on which the meaning of the event depends. 


\subsection{Strategies and Functions of Chinese Proverb Quoting}

A glance at the proverbs above demonstrates that China-Japan either disagreements or cooperation becomes a target of proverbial interpretation in the Chinese press. However, the analysis of the contemporary mass media of China proves that a proverbial scenario is more frequently applied to controversial issues, disputes, and disagreements, besides they present more variation and diversity of a proverb use.

It should be noted that in the Chinese press international events coverage is frequently based on politicians', statesmen's, and spokesmen's public speeches and interviews, in which the officials readily quote Chinese proverbs. In the cases when they employ proverbs to describe controversial aspects of international relations, a proverb (i.e. folk wisdom) passes a judgment clearly calling for adequate steps for resolving a conflict, or smoothing a clash of interests. Therefore, the Chinese proverb quotations are intended to be a tool of a conflict management.

The conflict management strategy realized through the use of proverbs (see also Almajir; Makamani, 2013) is habitually practiced in the English- and the Russian-language press of China. As in Adegoju (2009) who analyzed Yoruba proverbs of Africa "some proverbs center on the rule of conduct for handling conflict situations." (p. 67). The scholar emphasized "Persuasive effectiveness of the proverbs toward understanding conflict situations and devising strategies for resolving them" (p. 55).

The pragmatic force of Chinese proverbs in the analyzed media fragments is their immense analogy capacity, their strong power of bringing about mental resemblance of the "source" (proverbial) situation to the "target" (media described) scenario due to bright images and indisputable truth transmitted by proverbs. The above-mentioned proverb 吴越同舟 [being in the same boat] as Cai Hong (2014) points out "alludes to an episode in ancient China in which combatants from the warring states of $\mathrm{Wu}$ and Yue found themselves in the same boat on a river in a storm. Despite their hatred for each other, they agreed to lay down their weapons for common passage." (Cai Hong, 2014, October 21). This proverbial scenario was intended for its application to current Cino-Japanese bilateral relations: "The people of $\mathrm{Wu}$ and Yue states offer a lesson for us in modern times: When they bent their energies in a single direction, they weathered the storm." (Cai Hong, 2014, October 21).

Analogy underlies the proverb quotation 'Lose an axe and suspect a neighbor' (失斧疑邻) in the Chinese mass media description of Japan's plans to join collective self-defense: "Chinese Foreign Ministry spokeswoman Hua Chunying said on Monday that any policy adjustments on Japan's military security should not harm China's sovereignty and security interests. $<\ldots>$ Hua quoted a Chinese proverb: 'Lose an axe, and blame the neighbor' to make an analogy. The expression describes those who ignore the facts and make wrong assumptions about of people or situations." (Japan's security should not harm China's sovereignty, 2014, June 17).

Interestingly, the analogy works well only if the target audience knows the proverb's meaning and even much better if the readers or listeners are aware of the parable or allegorical story behind the proverb. In the case with 'Lose an axe and suspect a neighbor' the parable says that a man who lost his axe erroneously blamed his neighbor's son. The man did it by misinterpreting child's expressions, words and actions. When two days later he found his axe the same words and actions of his neighbor's son didn't seemed to him those of a thief at all. Probably Japan planning to exercise its right to collective self-defense is viewed through the proverbial analogy as misinterpreting China's actions and words.

Alongside with the analogy, the cause and effect logic is another mental procedure, which numerous Chinese proverbs evoke. Let us consider The Global Times news item (Chinese spokeswoman blames Japan for tension, 2013 March 04), which cited Fu Ying, spokeswoman for the first session of the $12^{\text {th }}$ National People's Congress (NPC), who commenting on Diaoyu Islands territorial dispute employed the Chinese proverb, the English version of which is 'it is impolite not to reciprocate' 來而不往非禮也 (meaning: friendship cannot stand always on one side).

The proverb was used in the cause and effect function intended to create in people's minds the idea of obligation to respond to Japan. This logic provides reasonable ground for China's reciprocal action: if the other party (Japan) "chooses to take tougher measures and abandon consensus, 'it is impolite not to reciprocate," "That's the reason why China sent patrol vessels to the Diaoyu Islands area." (Chinese spokeswoman blames Japan for tension, 2013, March 04). The Chinese proverb in the example above helps inform the world of the official China's attitude towards the events. 


\subsection{Cross-Cultural Pragmatics of Chinese Proverb Quoting: a Case Study}

Tannen (1984) points out that "Communication is, by its very nature, culturally relative." (p. 194). Cross-cultural communication however is double "culturally relative" for the addressor and the addressee in their alternative roles act in compliance with their cultural pragmatics. The addressor's communicative intent (whatever it is) complies with his/her culturally-based cognition, values, and worldview on the one hand, and on the other targets the addressee's no less culturally-based cognition, values, and worldview.

As Anna Wierzbicka (2003) states "researchers in cross-cultural pragmatics try to explain differences in the way of speaking in terms of values such as 'directness' or 'indirectness', 'solidarity', 'spontaneity', 'sincerity', 'social harmony', 'cordiality', 'self- assertion', 'intimacy', 'self-expression', and so on” (p. 70). In cross-cultural communication the addressor, being in rapport with the addressee, especially when both belong to the same "in-group", sharing the same background knowledge, views and attitude is apt to shift to high-context mode of communication with its full share of indirectness and informality.

In this respect cross-cultural pragmatics probably accounts for the differences between presenting news in the English-language mass media of China and the Russian-language Chinese press. The research provided some facts that the English-language newspapers employ proverbs to describe controversial issues in a more formal and direct way, whereas the Russian-language Chinese media presents some proverb quotations in informal and indirect style. This can be proved by the following example, which became the focus of the case study.

The Russian version of The People's Daily (Povedenie Japonii mozhno obojznachit slovami poslovitsy [Japan's behavior can be defined with the proverbs], 2014, June 13) cited the Foreign Ministry spokeswoman Hua Chunying, who commented on a close encounter between Chinese and Japanese planes over the East China Sea, and the so called "China threat" using the following proverbs:

1. 'a thief crying stop thief' [贼喊捉贼 , meaning: accuse sb. of the theft and try to sneak away oneself],

2. 'put the blame on the victim' [倒打一耙 , meaning: make false countercharges].

The first of the two proverbs was given in Russian as a loan translation, the second - as a Russian equivalent. Both proverbs were used in the heading of the news item in Russian and their recognizable images made the heading allegorically indirect and rather informal.

The headlines in the English version of The People's Daily are formal, direct, and not proverbial: "China urges Japan to stop provocations after jet encounter" (Wu Yanping, 2014, June 13) and "China blames Japan for warplane encounter over East China Sea" (Liang, 2014, June 13).

The texts of both articles in English provide citation of the Foreign Ministry spokeswoman Hua Chunying but lack proverbial expressions as seen from the example below: "The tension was completely triggered by dangerous acts of Japanese warplanes towards a Chinese warplane, while Japan disregards the facts and makes a false countercharge, openly defames China and hypes up the so-called China threat." (Liang, 2014, June 13).

The headlines of The China Daily also lack proverbs: "Japan's accusation against China only excuse for military build-up." (Japan's accusation against China, 2014, June 15). The text of the news however cites one of them: "The Chinese Defense Ministry on Thursday criticized Japan's provocative action and accusation, describing it as 'a thief who cries thief.' It seems Japan is again turning to old tricks in a bid to promote its theory that China is a threat." (Japan's accusation against China, 2014, June 15).

The discrepancy between proverb quoting in the case above can be considered in terms of cross-cultural pragmatics with China - the addressor and other cultures - addressees. Probably, the target audience and the choice in favor of high or low context communication determine the appropriateness of a proverbial quotation, as well as the forms in which a proverb is employed whether as a loan translation or an equivalent. The English-language version of Chinese papers is mainly (but not solely) targeted at native English-speakers, the audience being characterized by a low-context communication. For example as in E. Hall and M. Hall (1990) American culture "does not favor extensive, well-developed, informal information." (p. 9).

Russian culture is characterized as a high-context communication, and this may be the reason for informal details and hints transmitted by Russian equivalents of Chinese proverbs cited in the Russian version of newspapers. Besides, Russia is most probably perceived as a closest neighbor, a member of the so called in-group which, sharing with China not only border but also views and attitudes, is familiar with detailed and informal information.

The results of Chinese proverbs quoting in the English- and the Russian-language mass media of China concerning Cino-Japanese relations are presented in Table 1. 
Table 1.China-Japan Bilateral Relations through Chinese Mass Media Proverbs Quoting

\begin{tabular}{|c|c|c|}
\hline News topic & $\begin{array}{l}\text { A Chinese proverb quoted and its } \\
\text { general meaning (Source Scenario) }\end{array}$ & $\begin{array}{l}\text { Contextual meaning of a Chinese proverb (Target } \\
\text { Scenario) }\end{array}$ \\
\hline \multirow[b]{2}{*}{$\begin{array}{l}\text { Diaoyu Islands } \\
\text { territorial disputes }\end{array}$} & $\begin{array}{l}\text { 'one hand alone can't clap' (the } \\
\text { responsibility lies with both parties) }\end{array}$ & Japan has failed to engage in negotiations. \\
\hline & $\begin{array}{l}\text { 'it is impolite not to reciprocate' } \\
\text { (friendship cannot stand always on } \\
\text { one side) }\end{array}$ & $\begin{array}{l}\text { Other party (Japan) chooses to take tougher measures } \\
\text { and abandon consensus, so China sent patrol vessels } \\
\text { to the Diaoyu Islands area. (Chinese spokeswoman } \\
\text { blames Japan for tension, 2013, March 4). }\end{array}$ \\
\hline $\begin{array}{lcr}\text { Japan wants to } & \text { to } \\
\text { exercise right to } & \text { to } \\
\text { collective self-defense, } \\
\text { the use of force to } \\
\text { settle international } \\
\text { disputes }\end{array}$ & $\begin{array}{l}\text { 'lose an axe, and blame the neighbor' } \\
\text { (ignore the facts and make wrong } \\
\text { assumptions about people or } \\
\text { situations) }\end{array}$ & $\begin{array}{l}\text { Japan's military security should not harm China's } \\
\text { sovereignty and security interests. (Japan's security } \\
\text { should not harm China's sovereignty, 2014, June 17). }\end{array}$ \\
\hline \multirow[b]{2}{*}{$\begin{array}{l}\text { Chinese Premier visits } \\
\text { Japanese disaster } \\
\text { areas to boost } \\
\text { China-Japan ties }\end{array}$} & $\begin{array}{l}\text { 'a good neighbor is better than a } \\
\text { brother far away' }\end{array}$ & $\begin{array}{l}\text { Mutually beneficial strategic relations with } \\
\text { neighboring Japan. }\end{array}$ \\
\hline & 'a friend in need is more precious' & $\begin{array}{l}\text { Chinese Premier visits Japanese disaster areas } \\
\text { Fukushima nuclear power plant accident to offer } \\
\text { encouragement to the Japanese citizens (Chinese } \\
\text { Premier visits Japanese disaster areas to boost } \\
\text { China-Japan Ties, 2011, May 26). }\end{array}$ \\
\hline $\begin{array}{l}\text { "Candid exchanges" } \\
\text { crucial r to } \\
\text { China-Japan ties }\end{array}$ & $\begin{array}{l}\text { 'cooperation benefits both while } \\
\text { confrontation can only hurt' }\end{array}$ & $\begin{array}{l}\text { Long-term cooperation and friendship is the only } \\
\text { choice for both countries. (Li Xing \& Li Xiaokun. } \\
\text { 2010, September 01). }\end{array}$ \\
\hline $\begin{array}{l}\text { A close encounter } \\
\text { between Chinese and } \\
\text { Japanese military } \\
\text { planes over the East } \\
\text { China Sea }\end{array}$ & $\begin{array}{l}\text { 'a thief who cries thief' (accuse sb. of } \\
\text { the theft and try to sneak away } \\
\text { oneself) }\end{array}$ & $\begin{array}{l}\text { Japan's recent charge that Chinese jet fighters drew } \\
\text { "unusually close" to its military aircraft on a } \\
\text { provocative flight over the East China Sea is simply a } \\
\text { cover for its despicable plan for a military build-up. It } \\
\text { seems Japan is again turning to old tricks in a bid to } \\
\text { promote its theory that China is a threat. (Japan's } \\
\text { accusation against China, 2014, June 15). }\end{array}$ \\
\hline $\begin{array}{l}\text { A close encounter } \\
\text { between Chinese and } \\
\text { Japanese military } \\
\text { planes over the East } \\
\text { China Sea }\end{array}$ & $\begin{array}{l}\text { 'a thief crying Stop thief' (accuse sb. } \\
\text { of the theft and try to sneak away } \\
\text { oneself) } \\
\text { 'put the blame on the victim' (make } \\
\text { false countercharges) }\end{array}$ & $\begin{array}{l}\text { Japan falsifies the facts and shows black as white. } \\
\text { (Povedenie Japonii mozhno obojznachit slovami } \\
\text { poslovitsy [Japan's behavior can be defined with the } \\
\text { proverbs], 2014, June 13). }\end{array}$ \\
\hline $\begin{array}{l}\text { Japan, China can } \\
\text { cooperate }\end{array}$ & 'being in the same boat' & $\begin{array}{l}\text { The people of } \mathrm{Wu} \text { and Yue states offer a lesson for us } \\
\text { in modern times: When they bent their energies in a } \\
\text { single direction, they weathered the storm. (Cai } \\
\text { Hong, 2014, October 21). }\end{array}$ \\
\hline $\begin{array}{l}\text { Japan must own up to } \\
\text { militarist past }\end{array}$ & $\begin{array}{l}\text { 'blood will have blood, blood } \\
\text { demands blood' } \\
\text { 'recompense injury with justice' } \\
\text { 'vengeance has a way of rebounding } \\
\text { upon oneself' }\end{array}$ & $\begin{array}{l}\text { China is commemorating the } 120^{\text {th }} \text { anniversary of the } \\
\text { first Sino-Japanese War. History is a mirror, and it } \\
\text { has to be reviewed to build a better future, not to } \\
\text { generate hatred, which means Japan can ensure its } \\
\text { long-term development and regional security only } \\
\text { after admitting its militarist past. (Sun, 2014, } \\
\text { September 03). }\end{array}$ \\
\hline
\end{tabular}

\section{Conclusion}

Mass media of PRC in languages others than Chinese native (in the present research English and Russian) are a form of cross-cultural communication between China and the rest of the world, which proved to be determined by both pragmatic intentions of China and its prognosis for decoding these intentions by foreign target audience. On the one hand, by foreign-language media China demonstrates not only its views and attitudes to the events 
described, but also China "the whole self" employing fragments of its traditional verbal culture. Proverbs in particular are the ways of self-expression and self-assertion.

On the other hand, the foreign-language press of China thoroughly considers the appropriateness of proverb quotations, and estimates the degree of transmitted by them informal and indirect culture-based information, which the foreign audience is capable or incapable to grasp, share, and abide by. Proverbs generally being among the most indirect and roundabout strategies of reasoning and persuasion in some contextual use may convey straightforward and strict judgments.

This accounts for the difference between the information presentation in the English-language press of PRC and the Russian-language periodical of China particularly (in this research) in reference to Cino-Japanese relations coverage. The appropriateness of proverb quoting depends on crucial questions of cross-cultural pragmatics: first, the addressor's urge for culture relevant self-expression, on the one hand, and striving for intelligibility to target cultures-addressees, on the other, and second, the addressor's preferred mode of lower or higher context communication with different cultures-addressees.

Both questions suggest a wide range of options in proverb quoting (preserving/omitting a proverb, original proverb with glossing / loan translation, meaning / connotation modulation of a proverb, etc). Proverbial interpretation of events available in the original source of information (officials' public speech or interview) may be either preserved in news coverage or drastically altered (whether as a loan translation or an equivalent), and even omitted in foreign-language press in accordance with the prognostic estimation of culture-based perception of the audience.

Chinese proverbs employed for comments on China-Japan controversial issues and disagreements serve as a tool of a conflict management. The pragmatic intent of a Chinese proverb use in news coverage is "guided" logical or analogical reasoning. Even if foreign readers are not aware of the particulars of the event they get the message of the proverb to understand the meaning of the news issue.

\section{Acknowledgments}

The project was supported by the Scientific Fund of Far Eastern Federal University and the Research Grant 1466.2015 "Intercultural Communication in Asia Pacific: Interdisciplinary Approach".

\section{References}

Adegoju, A. (2009). Rhetoric in conflict-related yoruba proverbs: Guide to constructive conflict resolution in Africa. African Study Monographs, 30(2), 55-69. Kyoto University.

Almajir, T. K. Magana proverb as a conflict resolution mechanism in Hausa society. Retrieved from http://www.academia.edu/7782441/Karin_Magana_Proverb_as_a_Conflict_Resolution_Mechanism_in_Ha usa_Society_TijjaniShehuAlmajir_almajir02_at_yahoo.com_234_0_8035943092_Center_for_the_Study_of _Nigerian_Languages

Cai Hong. (2014, October 21). Japan, China can share the same boat. The China Daily. Retrieved from http://africa.chinadaily.com.cn/opinion/2014-10/21/content_18774650_2.htm

Chilukuri, B. (2014). The proverb and its 44 definitions (Part I): A Ka:rmik linguistic review with a checklist. Retrieved from http://www.academia.edu/4295188/The_Proverb_and_Its_44_Definitions_Part_I_A_Ka_ rmik_Linguistic_Review_with_a_Checklist 2.01/2014

Chinese Premier visits Japanese disaster areas to boost China-Japan Ties. (2011, May 26). The People's Daily. Retrieved from http://en.people.cn/90001/90776/90883/7391910.html

Chinese spokeswoman blames Japan for tension. (2013, March 4). The Global Times. Retrieved from http://www.globaltimes.cn/content/765667.shtml

Dabaghi, A., Pishbin, E., \& Niknasab, L. (2010). Proverbs from the viewpoint of translation. Journal of Language Teaching and Research, 1(6), 807-814. http://dx.doi.org/10.4304/jltr.1.6.807-814

Hall, E. (1989). Beyond culture. New York, NY: Anchor Books.

Hall, E., \& Hall, M. (1990). Hidden differences. Key concepts. New York, NY: Anchor Books.

Japan's accusation against China only excuse for military build-up. (2014, June 15). The China Daily. Retrieved from http://usa.chinadaily.com.cn/china/2014-06/15/content_17587989.htm

Japan's security should not harm China's sovereignty. (2014, June 17). The People's Daily. Retrieved from http://en.people.cn/n/2014/0617/c90883-8742006.html 
Li, X., \& Li, X. (2010, September 1). Candid exchanges' crucial for future. The China Daily. Retrieved from http://usa.chinadaily.com.cn/2010-09/01/content_11240335.htm

Liang, J. (2014, June 13). China blames Japan for warplane encounter over East China Sea. The People's Daily. Retrieved from http://en.people.cn/n/2014/0613/c90883-8740688.html

Liu, S. (2000). Pragmatics. In M. Byram (Ed.), Encyclopedia for language teaching and learning (pp. 382-384). London, England: Routledge. http://dx.doi.org/10.4324/9780203219300

Makamani, R. (2013). African proverbs and conflict management: A study of selected Shona, Oshivambo, Yoruba and Swahili proverbial expressions. African Journal of Rhetoric, 4, 122-149.

Mieder, W. (1997a). Modern paremiology in retrospect and prospect. Paremia, 6, 399-416.

Mieder, W. (1997b). The politics of proverbs: From traditional wisdom to proverbial stereotypes. Madison, Wisconsin: University of Wisconsin Press.

Mieder, W. (2004). Proverbs: A handbook. Greenwood Folklore Handbooks. Greenwood Press.

Mieder, W. (2005). Proverbs are the best policy: Folk wisdom and American politics. Logan, Utah: Utah State University Press.

Mieder, W. (2010). The golden rule as a political imperative for the world president Barack Obama's proverbial messages abroad. Millî Folklor, Y>l 22, Say> 85, 26-35. Retrieved from http://www.millifolklor.com

Norrick, N. R. (1985). How proverbs mean: Semantic studies in English proverbs. Berlin: Walter de Gruyter. http://dx.doi.org/10.1515/9783110881974

Povedenie Japonii mozhno obojznachit slovami poslovitsy. (2014, June 13). [Japan's behavior may be defined with the proverbs]. The People's Daily (in Russian). Retrieved from http://russian.people.com.cn/ $\mathrm{n} / 2014 / 0613 / \mathrm{c} 31521-8740775 . \mathrm{html}$

Scarborough, W. (1875). A collection of Chinese proverbs translated and arranged. With an introduction, notes, and copious Index. Shanghai: American Presbyterian mission press.

Sun, X. (2014, September 3). Japan must own up to militarist past. The China Daily. Retrieved from http://www.chinadaily.com.cn/opinion/2014-09/03/content_18537657_2.htm

Tannen, D. (1984). The Pragmatics of cross-cultural communication. Applied Linguistics, 5, 189-195.

Taylor, A. (1981). The wisdom of many and the wit of one. In W. Mieder, \& A. Dundes (Eds.), The wisdom of many: Essays on the proverb (pp. 3-9). Madison, Wisconsin: Univ of Wisconsin Press.

The China Daily Group. Retrieved January 20, 2015, from http://www.chinadaily.com.cn/static_e/ 2011about.html

The Global Times. Retrieved January 20, 2015, from http://www.globaltimes.cn/about-us

The People's Daily Online. Retrieved January 20, 2015, from http://en.people.cn/102840/8347294.html

Wierzbicka, A. (2003). Cross-cultural pragmatics: The semantics of human interaction. Berlin: Walter de Gruyter. http://dx.doi.org/10.1515/9783110220964

Wu, Y. (2014, June 13). China urges Japan to stop provocations after jet encounter. The People's Daily. Retrieved from http://en.people.cn/n/2014/0613/c90000-8741214.html

Yakovleva, E., \& Nikolaeva, O. (2014). Chinese paroemias as intertextual insertions in American mass media and social media discourse. Intercultural Communication Studies, XXIII(1), 146-164.

Zhao, W. (2012). An analysis of social proverbs from the perspective of cultural semiotics. Theory and Practice in Language Studies, 2(10), 2073-2080. http://dx.doi.org/10.4304/tpls.2.10.2073-2080

\section{Copyrights}

Copyright for this article is retained by the author(s), with first publication rights granted to the journal.

This is an open-access article distributed under the terms and conditions of the Creative Commons Attribution license (http://creativecommons.org/licenses/by/3.0/). 